Creative commons User License: CC BY-NC-ND

Abstracted by: EBSCOhost, Electronic Journals Service (EJS),

Google Scholar, Directory of Open Access Journals (DOAJ),

Journal Seek, Scientific Commons,

Food and Agricultural Organization (FAO), CABI and Scopus
Journal of Agricultural Extension

Vol. 21 (2) June, 2017

ISSN(e): 24086851; ISSN(Print); 1119944X

http://journal.aesonnigeria.org

http://www.ajol.info/index.php/iae

Email: editorinchief@aesonnigeria.org

\title{
Access and Use of Information and Communication Technologies by Extension Workers in Anambra State Agricultural Development Programme, Nigeria
}

https://dx.doi.org/10.4314/jae.v21i2.13

\section{Enwelu, I. A.}

Department of Agricultural Extension

University of Nigeria, Nsukka, Enugu State, Nigeria

Email: enwachonamin@yahoo.com +2348035090033

\section{Enwereuzor, S. O.}

Department of Agricultural Extension

University of Nigeria, Nsukka, Enugu State, Nigeria

Email: marisstella28@yahoo.com +2347039335523

\section{Asadu, A. N.}

Department of Agricultural Extension

University of Nigeria, Nsukka, Enugu State, Nigeria

Email: anthonia.asadu@unn.edu.ng +2348166979076

\section{Nwalieji, H. U.}

Department of Agricultural Economics and Extension

Chukwuemeka Odumegwu Ojukwu University, Igabriam Campus

Anambra State, Nigeria

Email: nwalieji73@yahoo.com +2347033994751

\section{Ugwuoke B. C.}

Department of Agricultural Extension

University of Nigeria, Nsukka, Enugu State, Nigeria

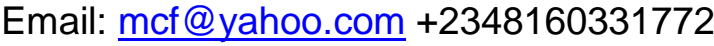

\begin{abstract}
The study examined access and use of information and communication technologies (ICTs) in Anambra State Agricultural Development Programme (ADP). A multi stage sampling technique was used in selecting respondents from the zones, blocks and circles. Questionnaire was used to collect data from 69 respondents. Data were analyzed using descriptive statistics, exploratory factor analysis and simple linear regression. Mobile phone $(\bar{x}=3.42)$ was highly accessible to extension workers. Also, mobile phone was available in ADP office and very often used. Factors that militated against extension workers' access and use of ICTs were: poor ICT skills, inadequate support by organization and government and high cost of maintenance of ICT tools. The number of ICTs owned showed significant influence on level of ICTs utilization among extension workers. Access and use of ICT in Anambra State ADP was relatively low and there is need for an intervention by governments and nongovernmental organizations.
\end{abstract}

Keywords: ICT access and use, Anambra State ADP 
Creative commons User License: CC BY-NC-ND

Abstracted by: EBSCOhost, Electronic Journals Service (EJS), Google Scholar, Directory of Open Access Journals (DOAJ), Journal Seek, Scientific Commons,

Food and Agricultural Organization (FAO), CABI and Scopus
Journal of Agricultural Extension

Vol. 21 (2) June, 2017

ISSN(e): 24086851; ISSN(Print); $1119944 X$

http://journal.aesonnigeria.org

http://www.ajol.info/index.php/jae

Email: editorinchief@aesonnigeria.org

\section{Introduction}

Nigeria has an agricultural research system made up of 17 commodity-based research institutes and a special national extension institute of over 45 faculties of agriculture in conventional federal, state, and private universities (Saliu and Age, 2009). The important task of extension is the exchange and sharing of information, knowledge and skills.

The Agricultural Development Programme (ADP) plays an important role in extension service delivery in the agricultural sector. ADPs liaise with the research institutes for improved technologies in order to effectively deliver services to the farmers. The urgent need for current agricultural knowledge and information system (AKIS) by farmers calls for the adoption of information and communication technologies (ICTs) by extension workers to transmit relevant information to farmers in a most efficient way (Salau and Saingbe 2008).

Kemp in Tiwari, Tiwari and Sharma (2015) reports that information is considered as the fifth need of man ranking after air, water, food and shelter. Therefore, the concept of information in general and of agricultural information in particular, as a resource for development is very important in the contemporary world and cannot be overemphasized (Ogbonna and Agwu, 2013). In most of sub-Saharan African countries, conventional media for example radio, newspapers and television have played key roles in rural development. Agricultural innovations are disseminated to rural farmers through these media. Unfortunately, according to Orikpe and Orikpe (2013), in Nigeria, extension agents still depend heavily on traditional extension methods of communication. This is no longer effective for the time bound research discoveries and the high farmer extension agent ratio in the new millennium. The extent to which the extension agents effectively carry out the all important function of communicating with the farmers leaves much to be desired.

However, with ICTs, rural communities can acquire the capacity to improve their living conditions. ICTs have the potential to penetrate under-serviced areas and enhance education through distance learning, facilitate development of relevant local content and faster delivery of information on technical assistance and basic human needs such as food, agriculture, health and water. The internet for instance can enable the remotest village to access regular and reliable information from a global library or the web (Ozor and Madukwe, 2009).

Authors have conceptualized ICT as the set of technologies that facilitate information processing, storage, retrieval and transmission (Ozor and Madukwe, 2009). However, ICTs in a broader sense, refers to sets of tools, equipment, applications, and services that are utilized to produce, capture, store, disseminate and exchange information (Raji, 2008).

Meera, Jhamtani and Rao (2004) reiterate that ICT can be of immense help by enabling extension workers to gather, store, retrieve and disseminate a broad range of information needed by farmers, thus transforming them from extension workers into knowledge workers (KW). The emergence of such knowledge workers will result 
Creative commons User License: CC BY-NC-ND

Abstracted by: EBSCOhost, Electronic Journals Service (EJS),

Google Scholar, Directory of Open Access Journals (DOAJ),

Journal Seek, Scientific Commons,

Food and Agricultural Organization (FAO), CABI and Scopus
Journal of Agricultural Extension

Vol. 21 (2) June, 2017

ISSN(e): 24086851; ISSN(Print); $1119944 X$

http://journal.aesonnigeria.org

http://www.ajol.info/index.php/jae

Email: editorinchief@aesonnigeria.org

in the realization of the much talked about bottom-up, demand-driven technology generation, assessment, refinement and transfers.

However, it is not sure whether the extension workers utilize the necessary ICTs in contacting the farmers, especially in Anambra State ADP. Ovwigho, Ifie, Ajobo, and Akor (2009) observe that in most Nigerian rural communities, extension workers have used different types of ICTs which included radio, drama, and video/television.

On the other hand, Abdulsalam, Akinola and Buwanhot (2008) report that access to ICT facilities is generally poor in Nigeria. This view is supported by the findings of Ogbonna and Agwu (2013) that most rural communities in Nigeria do not have access to major ICT facilities. Where access to ICT is generally poor in a community, extension workers may be constrained in its effective usage. The poor access to ICT facilities in Nigeria suggests that ICT usage will also not be efficient and effective. According to Arinze, Okonkwo and, Iwunor (2012), the impact of ICT use in extension delivery still remained minimal.

Consequently, the following questions become pertinent: What are the types of ICTs owned by extension workers and those available in Anambra State ADP? What access do extension workers have to ICTs in Anambra State ADP? What is the level of use of ICTs owned by extension workers and the ones available in Anambra State ADP? What are factors constraining effective access and use of ICTs by extension workers? Answers to these questions are the main thrusts of the study.

The overall objective of the study was to ascertain access and use of ICTs by extension workers in Anambra State ADP. Specifically, the study sought to: identify the types of ICTs owned by extension workers and the ones available in Anambra State ADP; determine the accessibility of ICTs to extension workers in Anambra State ADP; and determine level of use of ICTs owned by extension workers and the ones available in Anambra State ADP. The null hypothesis for the study was: number of ICTs owned had no significant influence on level of ICTs utilization among extension workers.

\section{Methodology}

The study was carried out in Anambra State ADP, Nigeria. The population of the study comprised all the extension workers in Anambra State ADP and the multistage sampling technique was use in selecting the respondents. The Programme Manager (PM) and all the four zonal managers were selected. Four subject matter specialists (SMS) were randomly selected (one from each of the four zones) while four block extension supervisors (BESs) were selected from each of the four zones. The number of block extension supervisors in each zone included: Aguata Zone, 6 blocks; Anambra Zone, 5 blocks; Awka Zone, 4 blocks; and Onitsha Zone ,6 blocks). Thereafter, one block extension agent (BEA) was randomly selected from each of the four zones. Finally, two field extension agents (EAs) were also randomly selected in each block to give a total of 42 out of which 40 were finally used. On the whole, a total of 69 respondents were involved in the study. 
Creative commons User License: CC BY-NC-ND

Abstracted by: EBSCOhost, Electronic Journals Service (EJS),

Google Scholar, Directory of Open Access Journals (DOAJ),

Journal Seek, Scientific Commons,

Food and Agricultural Organization (FAO), CABI and Scopus
Journal of Agricultural Extension

Vol. 21 (2) June, 2017

ISSN(e): 24086851; ISSN(Print); $1119944 X$

http://journal.aesonnigeria.org

http://www.ajol.info/index.php/jae

Email: editorinchief@aesonnigeria.org

Data for the study were obtained from primary sources. This was achieved through the use of questionnaire. The types of ICTs owned and the ones available in the state ADP were identified by asking the respondents to indicate the types of ICTs they own and the ones available in the state ADP. The accessibility of ICTs to extension in Anambra State ADP was determined by first asking the respondents to indicate among the listed ICTs the ones they have access to and were further requested to indicate their level of access on a four point Likert-type scale of: high access (4), moderate access (3), low access (2), no access (1). These values were summed up to 10 and divided by four to give a mean score of 2.5 . For instance, if 50 respondents indicated high access, it means 50 multiplied by four and divided by total number of respondents $(50 \times 4=200 ; 200 / 69=2.90)$. The level of use of ICTs owned by extension workers and the ones available in Anambra State ADP were also measured on four-point Liker-type scale of: very often (4), often (3), not often (2), not at all (1). Data were analyzed using descriptive statistics, exploratory factor analysis simple linear regression.

The simple linear regression model was given as:

$\mathrm{Y}=\mathrm{b}_{0}+\mathrm{b}_{1} \mathrm{X}_{1}$

Where $Y=$ Level of access to ICTs

b0 $=$ Constant

b1=coefficient of the independent variables (ICTs owned)

$\mathrm{X} 1=\mathrm{ICT}$ s owned.

\section{Results and Discussion}

\section{Type of ICT Owned by Extension Workers and Available in ADP Office}

Table 1 shows the ICTs owned by the respondents. A large proportion (87.7\%) of the respondents owned mobile phone, radio set $(62.9 \%)$, computer $(62.1 \%)$, internet $(56.9 \%)$ and email $(52.5 \%)$ which they may also use for office work. On the other hand, a small proportion owned fax machine (2.2\%), and multimedia projector $(8.2 \%)$ which they may also use for office work. Since ICTs can be used for personal and official purposes, this is a good development for effective dissemination of agricultural information to farmers by extension workers. Furthermore, computer $(80.6 \%)$ was readily available in the state ADP office. A proportion of ICTs such as: twitter (9.8\%), fax machine (12.9\%), facebook (13.1\%), and video CD player (15.3\%), were available in the state ADP.

The availability of old ICTs in Anambra State ADP is an indication of ineffective communication and interaction among extension workers and farmers. In other words, the implication of the finding is that it may be difficult to source major information necessary for extension work from internet and global library because of lack of high ICTs in the ADP office. Extension workers desiring to share information with entrepreneurial farmers are adversely affected when low ICTs are available in extension office and probably when handicapped in using owned ICTs. In other climes this is not what is obtainable. According to Narasimha (2013), television and internet are playing a vital role in facilitating faster dissemination of information 
Creative commons User License: CC BY-NC-ND

Abstracted by: EBSCOhost, Electronic Journals Service (EJS),

Google Scholar, Directory of Open Access Journals (DOAJ),

Journal Seek, Scientific Commons,

Food and Agricultural Organization (FAO), CABI and Scopus
Journal of Agricultural Extension

Vol. 21 (2) June, 2017

ISSN(e): 24086851; ISSN(Print); $1119944 X$

http://journal.aesonnigeria.org

http://www.ajol.info/index.php/jae

Email: editorinchief@aesonnigeria.org

and innovations in all walks of life. These media are acting as change agent in the lives of farming community in creating awareness and improving their knowledge due to the increased access to these gadgets by extension workers and farmers in India. Since extension work requires impacting to farmers the necessary skills to acquire agricultural information in timely manner, the need to create enabling environment for extension workers becomes imperative.

For instance, in India, the government made provision for extension workers to access agricultural information without stress. Narasimha (2013) reports that village Knowledge Centre is the common place in a village where every villager including extension workers can come and have access to computer. This kind of set up is required by extension workers to update their clientele with latest information for enhanced profitability of their farm enterprise.

Table 1: ICTs owned and those available in Anambra State ADP

\begin{tabular}{lcc}
\hline ICT Facilities & Owned (\%) & Available in Anambra State ADP (\%) \\
\hline Mobile telephone & 87.7 & 33.3 \\
Radio set & 62.9 & 42.1 \\
Computer & 62.1 & 80.6 \\
Internet & 56.9 & 23.0 \\
Email & 52.5 & 30.6 \\
Television set & 48.4 & 27.6 \\
Face-book & 44.1 & 13.1 \\
Video CD player & 37.3 & 15.3 \\
DVD & 37.0 & 21.3 \\
Twitter & 26.4 & 9.8 \\
Digital camera & 24.5 & 27.1 \\
Multimedia projector & 8.2 & 41.3 \\
Fax machine & 2.2 & 12.9 \\
\hline
\end{tabular}

*Multiple response

\section{Extension Workers Level of Access to Various ICTs in ADP Office}

Table 2 highlights extension workers level of access to various ICTs in ADP office. Data revealed that extension workers were highly accessible to mobile phone $(\bar{x}=3.42)$, radio set $(\bar{x}=2.79)$, and television set $(\bar{x}=2.70)$. However, the (modern or computer-based ICTs) such as multimedia projector $(\bar{x}=1.67)$, twitter $(\bar{x}=1.50)$, fax machine $(\bar{x}=1.30)$ which ideally conveys more vast current information were poorly accessible.

This finding is in agreement with the findings of Salau and Saingbe (2008) that extension workers in Nasarawa State have high percentage access to radio, television and mobile phone, while fewer (49\%) have access to computers, which they regarded as key to all ICT facilities. It is surprising that although respondents 
Creative commons User License: CC BY-NC-ND

Abstracted by: EBSCOhost, Electronic Journals Service (EJS),

Google Scholar, Directory of Open Access Journals (DOAJ),

Journal Seek, Scientific Commons,

Food and Agricultural Organization (FAO), CABI and Scopus
Journal of Agricultural Extension

Vol. 21 (2) June, 2017

ISSN(e): 24086851; ISSN(Print); 1119944X

http://journal.aesonnigeria.org

http://www.ajol.info/index.php/iae

Email: editorinchief@aesonnigeria.org

indicated that computer was readily available in ADP office but not very accessible to extension workers while available ICTs with very low proportion such as mobile phone, radio set and television are very accessible. In practice where ICT is available and accessible, it is a very powerful tool of extension workers to educate and inform farmers about new ideas, technologies and other information. The lack of access to modern or computer based ICTs can not only negatively affect extension workers but also their clientele. Narasimha (2013) is of the opinion that agriculture input marketing especially pesticides, fertilizers, seeds and farm equipments marketing, with its own peculiarities in terms of widespread customer base, multitier and multi-product distribution system to millions of farmers, can be improved through ICT application.

Table 2: Level of access to ICTs in ADP office

\begin{tabular}{lll}
\hline ICTS & Mean & Std. Deviation \\
\hline Mobile phone & $3.42^{*}$ & 0.97 \\
Radio set & $2.79^{*}$ & 1.12 \\
Television set & $2.70^{*}$ & 1.18 \\
Computer & 2.48 & 1.02 \\
Internet & 2.20 & 1.14 \\
Email & 2.06 & 1.16 \\
Video CD player & 1.87 & 1.06 \\
Facebook & 1.80 & 1.11 \\
DVD & 1.77 & 1.05 \\
Digital camera & 1.75 & 1.03 \\
Multimedia projector & 1.65 & 0.86 \\
Twitter & 1.50 & 0.89 \\
Fax machine & 1.30 & 0.63 \\
\hline
\end{tabular}

${ }^{*}$ Highly accessible

\section{Extension Workers Level of Use of ICTs Available in ADP Office}

Table 3 reveals the respondents' level of use of office ICTs. The ICTs used very often was mobile phones $(\bar{x}=2.72)$. The computer-based ICTs such as facebook $(\bar{x}=1.68)$, DVD $(\bar{x}=1.66)$, Twitter $(\bar{x}=1.58)$ were not often used.

The findings indicate that extension workers were using mainly the mobile phone. Similarly, in Malaysia, Salleh, et al. (2008) observed that the main networking tools used by extension workers were mobile phone and telephone. The implication of extension workers mainly phone is that a lot of information available in the internet and other e-library resources may not be available to them and the farmers. This is because according to them, the use of ICT particularly the internet will expose 
Creative commons User License: CC BY-NC-ND

Abstracted by: EBSCOhost, Electronic Journals Service (EJS),

Google Scholar, Directory of Open Access Journals (DOAJ),

Journal Seek, Scientific Commons,

Food and Agricultural Organization (FAO), CABI and Scopus
Journal of Agricultural Extension

Vol. 21 (2) June, 2017

ISSN(e): 24086851; ISSN(Print); $1119944 X$

http://journal.aesonnigeria.org

http://www.ajol.info/index.php/jae

Email: editorinchief@aesonnigeria.org

extension workers to new knowledge and new technology in agriculture. This justifies the findings of Isiaka et al. (2009) who opine that most of the extension workers are

not really conscious of the fact that ICT devices such as computer, internet and GSM can be used to efficiently accomplish numerous functions in extensions service delivery. Also, as indicated by Wijekon and Newton (2000), without being appropriately grounded in communication technology potentials, efficient utilization among the extension workers may not be realized.

Table 3: Level of use of office ICTs

\begin{tabular}{lll}
\hline ICT facilities & Mean & Std. deviation \\
\hline Mobile phone & $2.72^{*}$ & 1.26 \\
Computer & 2.20 & 1.04 \\
Radio set & 1.96 & 1.01 \\
Digital camera & 1.92 & 1.02 \\
Multimedia projector & 1.83 & 0.96 \\
Email & 1.82 & 1.05 \\
Television set & 1.81 & 0.98 \\
Internet & 1.77 & 1.00 \\
Video CD player & 1.73 & 0.09 \\
Face book & 1.68 & 0.90 \\
DVD & 1.66 & 0.92 \\
Twitter & 1.58 & 0.87 \\
Fax machine & 1.47 & 0.77 \\
\hline
\end{tabular}

${ }^{*}=$ used

\section{Level of use of extension workers' owned ICTs}

Table 4 shows that the owned ICTs used very often by extension workers for extension work were: mobile phone $(\bar{x}=3.82)$, computer $(\bar{x}=2.84)$, radio set $(\bar{x}=2.71)$, television $(\bar{x}=2.61)$ and internet $(\bar{x}=2.55)$. However, modern or computer based ICTs like multimedia projector $(\bar{x}=1.48)$, and fax machine $(\bar{x}=$ 1.32) were identified as poorly used ICTs by extension workers.

The versatility and portability of mobile phone may be the reason why it has the highest level of use. It is something they move about with and as such, information can be transferred or received at any point in time. However, level of use of mobile phone also depends mainly on availability of money to recharge the facilities and availability of networks. The high level of use of other owned high ICTs such as computer and internet for extension work is commendable. Nevertheless, this finding is contrary to Salleh et al. (2008) which state that only $36 \%$ of the respondents indicate that they have computer at their home and they use it mainly for the purpose of record keeping.

For the internet they indicate that one third of the respondents said that they have online services at their home while they used internet mainly for the purpose of seeking ICT information. The use of ICT particularly the internet will expose farmers 
Creative commons User License: CC BY-NC-ND

Abstracted by: EBSCOhost, Electronic Journals Service (EJS),

Google Scholar, Directory of Open Access Journals (DOAJ),

Journal Seek, Scientific Commons,

Food and Agricultural Organization (FAO), CABI and Scopus
Journal of Agricultural Extension

Vol. 21 (2) June, 2017

ISSN(e): 24086851; ISSN(Print); $1119944 X$

http://journal.aesonnigeria.org

http://www.ajol.info/index.php/iae

Email: editorinchief@aesonnigeria.org

to knowledge and new technology in agriculture. Since the extension workers claim a higher ownership of these ICTs, the probability of use is also relatively high.

Table 4: Level of use of personal ICTs

\begin{tabular}{lll}
\hline ICTs & Mean $(\bar{x})$ & Std. Deviation \\
\hline Mobile phone & $3.82^{*}$ & 0.61 \\
Computer & $2.84^{*}$ & 1.06 \\
Radio set & $2.71^{*}$ & 1.17 \\
Television set & $2.61^{*}$ & 1.14 \\
Internet & $2.55^{*}$ & 1.20 \\
Facebook & 2.09 & 1.11 \\
Email & 2.06 & 1.16 \\
Video CD player & 2.03 & 1.08 \\
DVD & 1.87 & 1.09 \\
Digital camera & 1.83 & 0.96 \\
Multimedia projector & 1.48 & 0.73 \\
Fax machine & 1.32 & 0.57 \\
\hline
\end{tabular}

${ }^{*}=$ Used

\section{Factors militating extension workers access and use of ICTs}

Table 5, shows the three factors extracted as problems as user personal related, office/work, and ICT Technicality. Factor 1(user personal related factor) was dominated by: poor ICT skills (0.85) lack of adequate time (0.82), poor knowledge of ICTs (0.80), lack of effective training on ICT (0.63), lack of information from research institute (0.50) and erratic power supply (0.41). Factor 2 (office /work related factor) included: inadequate support by organizations and government (0.74), negative attitude of people to change (0.73), heavy workload/inadequate number of workers (0.68), unavailability of hardware required by modem ICT (0.64) and negative attitude of farmers in using ICT tools (0.56). Factor 3 (ICT Technicality related factor) were: high cost of ICT maintenance/use (0.82), poor maintenance of ICT hardware (0.77), complexity in using ICT (0.58) and lack of internet access and network services for ICT facilities (0.50).

The implication is that extension workers are adversely affected by three major factors or problems (personal problem, office related problem and technicality problem) that have capacity to mar their ability to empower their clientele with necessary information. For instance, the inability of extension workers to acquire the necessary skills in the use of high ICTs can affect the type of information and the tools with which they can convey information to farmers. This finding is similar to that of Salleh et al. (2008) that problems and obstacles in using ICT include: ignorance of the benefits of using ICT; lack of skill in using ICT; lack of time to use ICT; difficulty in using ICT; and lack of knowledge in using ICT. However, personal interview with management staff revealed that lack of modern ICTs in the state ADP and decreasing number of extension workers were the major constraints faced by the 
Creative commons User License: CC BY-NC-ND

Abstracted by: EBSCOhost, Electronic Journals Service (EJS),

Google Scholar, Directory of Open Access Journals (DOAJ),

Journal Seek, Scientific Commons,

Food and Agricultural Organization (FAO), CABI and Scopus
Journal of Agricultural Extension

Vol. 21 (2) June, 2017

ISSN(e): 24086851; ISSN(Print); $1119944 X$

http://journal.aesonnigeria.org

http://www.ajol.info/index.php/jae

Email: editorinchief@aesonnigeria.org

extension agency. This view is collaborated by NAERLS (2012) which confirms that the number of extension agents in many States is decreasing as a result of

retirements, death and movement of staff to other jobs. The increasing workload as a result of reduction in workforce and subsequent pressure of time may be part of the same problem.

Table 5: Constraints against extension workers' access and use of ICTs

\begin{tabular}{|c|c|c|c|}
\hline Constraints & Personal & Office or work & Technicality \\
\hline Poor knowledge of ICTs & 0.80 & 0.03 & 0.04 \\
\hline Lack of adequate time & 0.82 & 0.21 & 0.02 \\
\hline High cost of ICT maintenance & 0.51 & 0.10 & 0.54 \\
\hline Erratic power supply & 0.41 & -0.01 & 0.13 \\
\hline Poor maintenance of ICT hardwares & 0.12 & 0.17 & 0.78 \\
\hline $\begin{array}{l}\text { Lack of internet access and network } \\
\text { services for ICT facilities }\end{array}$ & 0.01 & 0.34 & 0.50 \\
\hline Lack of information from research institute & 0.50 & 0.32 & 0.14 \\
\hline $\begin{array}{l}\text { Heavy work load/inadequate number of } \\
\text { workers }\end{array}$ & 0.31 & 0.68 & -0.11 \\
\hline Poor ICT skills & 0.85 & 0.13 & 0.21 \\
\hline Lack of effective training on ICT & 0.63 & 0.31 & 0.23 \\
\hline High cost of maintenance/use & 0.14 & 0.19 & 0.82 \\
\hline Low ICT literacy & 0.61 & -0.07 & 0.48 \\
\hline Complexity in using ICT & 0.20 & 0.16 & 0.59 \\
\hline $\begin{array}{l}\text { Negative attitude of farmers in using ICT } \\
\text { tools }\end{array}$ & -0.219 & 0.58 & 0.15 \\
\hline $\begin{array}{l}\text { Inadequate support by organizations and } \\
\text { government }\end{array}$ & 0.21 & 0.74 & 0.00 \\
\hline Negative attitude of people to change & 0.11 & 0.73 & 0.17 \\
\hline $\begin{array}{l}\text { Unavailability of hardware required by } \\
\text { modem ICT }\end{array}$ & 0.21 & 0.64 & 0.22 \\
\hline Poor benefits in using ICT & 0.05 & 0.53 & 0.49 \\
\hline The fear of failure in using ICTs & 0.11 & 0.56 & 0.43 \\
\hline Illiteracy & 0.20 & -0.07 & 0.54 \\
\hline
\end{tabular}

Influence of respondents' personal ownership of ICTs on their level of ICTs utilization

Table 6 shows that the number of ICTs owned had a significantly influence on the respondents' level of ICTs utilization $(F=21.585, P=0.000)$ among the extension workers. With an adjusted $R$ squared value of 0.211 which means that the number of 
Creative commons User License: CC BY-NC-ND

Abstracted by: EBSCOhost, Electronic Journals Service (EJS),

Google Scholar, Directory of Open Access Journals (DOAJ),

Journal Seek, Scientific Commons,

Food and Agricultural Organization (FAO), CABI and Scopus
Journal of Agricultural Extension

Vol. 21 (2) June, 2017

ISSN(e): 24086851; ISSN(Print); $1119944 X$

http://journal.aesonnigeria.org

http://www.ajol.info/index.php/jae

Email: editorinchief@aesonnigeria.org

ICTs owned influences their level of ICTs utilization by about $21 \%$, which is a significant influence. This implies that the level of ICTs

utilization among the extension workers is a function of the number of ICTs owned by them. Therefore, the null hypothesis was rejected.

Table 6: Influence of respondents' personal ownership of ICTs' on level of ICTs utilization

\begin{tabular}{|c|c|c|c|c|}
\hline Model & $\begin{array}{l}\text { Unstandard } \\
\text { Coefficients } \\
\text { B }\end{array}$ & $\begin{array}{l}\text { ized } \\
\text { Std. Error }\end{array}$ & $\begin{array}{l}\text { Standardized } \\
\text { Coefficients } \\
\text { Beta }\end{array}$ & $\mathrm{t}$ \\
\hline (Constant) & 1.571 & 0.119 & & 13.259 \\
\hline $\begin{array}{l}\text { Number of ICTs } \\
\text { owned }\end{array}$ & 0.072 & 0.015 & 0.470 & $4.646^{*}$ \\
\hline
\end{tabular}

\section{Conclusion and Recommendations}

Extension workers had high access to mobile phone, but had low access to computer based ICTs like fax machine, twitter and multimedia projector. Personal ICTs used very often by extension workers were: mobile phone, computer and radio set. ICTs available in ADP office and used very often by extension workers was mobile phones. ICTs like face book, internet and twitter were not frequently used. Factors that militated against access and use of ICTs included poor knowledge of ICT, lack of adequate time and complexity in using ICT.

There is need for an intervention by governments and non-governmental organizations through establishment of ICT centers at village/community levels where extension workers and farmers meet at fixed days/weeks to share information, loan service, production input and other advisory services. Training of extension workers on the use of ICTs in working with farmers.

Coordinating the activities of internet service provider to make available toll free ICT facilities for extension services.

\section{Reference}

Anambra State Agricultural Development Project (1987). The Role and Functions of Extension Agents. A Paper presented at the Orientation course for new staff in Nsukka Zone, $8^{\text {th }}$ Dec.

Arinze, F.O. Okonkwo, E.N; Iwunor, A.N. (2012). Information and communication technology (ICT) Application in secondary schools and student's academic performance in Social Studies. African Research Review 6 (4):27

Federal Ministry of Agriculture and Rural Development (2000) Agriculture in Nigeria: the New Policy Thrust.

Meera, S.N. (2002). A Critical analysis of information technology in agricultural development: Impact and implications. PhD thesis, IARI, New Delhi-110012. 
Creative commons User License: CC BY-NC-ND

Abstracted by: EBSCOhost, Electronic Journals Service (EJS),

Google Scholar, Directory of Open Access Journals (DOAJ),

Journal Seek, Scientific Commons,

Food and Agricultural Organization (FAO), CABI and Scopus
Journal of Agricultural Extension

Vol. 21 (2) June, 2017

ISSN(e): 24086851; ISSN(Print); 1119944X

http://journal.aesonnigeria.org

http://www.ajol.info/index.php/jae

Email: editorinchief@aesonnigeria.org

Meera S.N, Jhamtani A, Rao DUM (2004). Information and communication technology in agricultural development: A comparative analysis of three projects from India'. Agric. Res. Exten. Network 135:13.

Narasimha, N. (2013). ICT- an innovative extension approaches in agriculture development EFITA-WCCA-CIGR Conference Sustainable AgricultureThrough ICT Innovation, Turin, Italy, 24-27 June.

National Agricultural Extension and Research Liaison Services (NAERLS) (2012). Executive Summary of Agricultural Performance Survey of 2012 Wet Season in Nigeria. October, 15

Ogbonna, O.I.; Agwu, A.E. (2013). Access and use of Information communication Technologies by Rural Farmers in Enugu North Senatorial Zone, Enugu State. Journal of Agricultural Science 3 (7): 264-270

Orikpe, E. A. and Orikpe, G. O. (2013). Information and communication technology and enhancement of agricultural extension services in the new millennium Journal of Educational and Social Research Vol. 3 (4) July, pp. 155-159

Ozor, N. and Madukwe, M. C. (2009). Role of information communication technology in agricultural development. In Echezona, B. C. (ed.). General Agriculture: Principles and Practices, Faculty of Agriculture, University of Nigeria, Nsukka. Pp. 20-24

Raji, A.O. (2008), The Role of Information and Communication Technologies in Revitalizing Agriculture in Nigeria, Paper presented at the First National Conference on Revitalizing Agriculture for Sustainable National Growth and stable Democracy, at Akperan Orshi, College of Agriculture Yandev, Benue State, Nigeria, October 22-23.

Salau E. S. and Saingbe N.D. (2008). Access and utilization of information and communication technologies (ICTs) among agricultural researchers and extension workers in selected institutions in Nasarawa State of Nigeria. Production Agriculture and Technology (PAT), Vol.4(2):1-11 Online copy available at www.patnsukjournal.com/currentissue

Salleh, H., Musa, A. H., Bahaman, A. S., Narimah, I. and Hayrol, A. M.S. (2008). Use of information and communication technology (ICT) among agri - based entrepreneurs in Malaysia, IAALD AFITA WCCA (World Conference on Agricultural Information) and IT, pp.753-762

Saliu, O.J and Age, A.I. (2009) privataization of agricultural extension services in Nigeria proposed guidelines for implementation. Journal of Sustainable Development in Africa 11(2).

Tiwari, M., Tiwari, N.S. and Sharma, R. (2015). Information and communication technology in academic libraries: how they are important today? International Journal of Applied Research 2015; 1(11): 668-672 